\title{
Graphene nanophotonics: From fundamentals to applications
}

\section{Xiao, Sanshui}

Link to article, DOI:

10.1109/PIERS.2016.7735215

Publication date:

2016

Document Version

Publisher's PDF, also known as Version of record

Link back to DTU Orbit

Citation (APA):

Xiao, S. (2016). Graphene nanophotonics: From fundamentals to applications. Abstract from EMN Light-Matter Interactions 2016, Singapore, Singapore. https://doi.org/10.1109/PIERS.2016.7735215

\section{General rights}

Copyright and moral rights for the publications made accessible in the public portal are retained by the authors and/or other copyright owners and it is a condition of accessing publications that users recognise and abide by the legal requirements associated with these rights.

- Users may download and print one copy of any publication from the public portal for the purpose of private study or research.

- You may not further distribute the material or use it for any profit-making activity or commercial gain

- You may freely distribute the URL identifying the publication in the public portal

If you believe that this document breaches copyright please contact us providing details, and we will remove access to the work immediately and investigate your claim 


\section{Graphene nanophotonics: From fundamentals to applications}

\section{$\underline{\text { Sanshui Xiao }}^{1,2}$}

${ }^{1}$ DTU Fotonik, Department of Photonics Engineering, Technical University of Denmark, 2800, Kgs. Lyngby, Denmark.

${ }^{2}$ Center for Nanostructured Graphene (CNG), Technical University of Denmark, DK-2800 Kgs. Lyngby, Denmark. mail:saxi@fotonik.dtu.dk,website: http://www.fotonik.dtu.dk/sem

With unique possibilities for controlling light in nanoscale devices, graphene has opened new perspectives to the nanophotonics community with potential applications in metamaterials, modulators, photodetectors, and sensors. Following a brief introduction of graphene, I will present recent our results on graphene, such as excitation of graphene plasmon polartions [1], pushing graphene plasmons to short wavelengths, and investigating of graphene plasmon-phonon interactions [2]. Finally I will discuss graphene-based optical modulators [3], particularly focusing on graphene-silicon platforms for electro-absorption modulating.
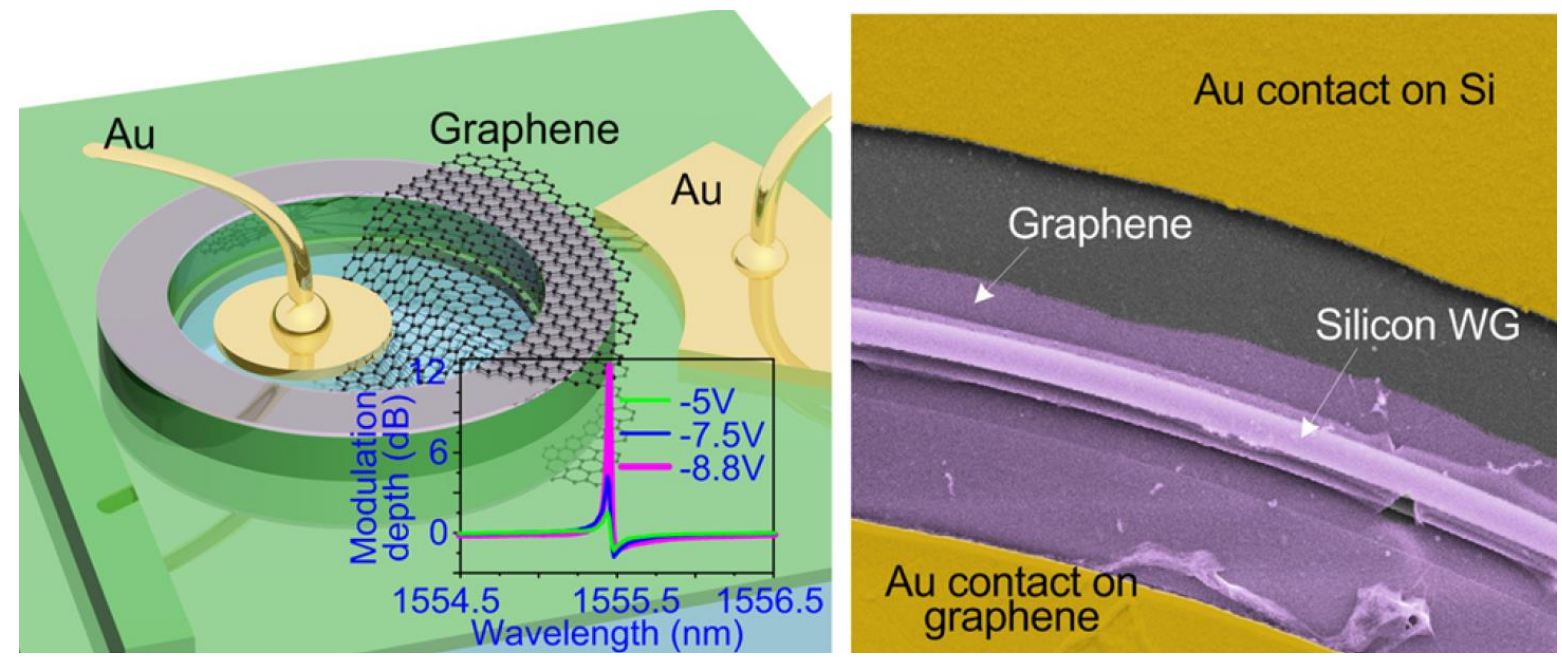

Fig. 1. Graphene based electro-optical modulator

References:

[1]. X. Zhu, W. Yan, P.U. Jepsen, O. Hansen, N.A. Mortensen, and S. Xiao, Appl. Phys. Lett., 102, 131101 (2013).

[2]. X. Zhu, W. Wang, W. Yan, M.B. Larsen, P. Bøggild, T. G. Pedersen, S. Xiao, J. Zi, and N. A. Mortensen, Nano Lett., 14, 2907 (2014).

[3]. Y. Ding, X. Zhu, S. Xiao, H. Hu, L.H. Frandsen, N.A. Mortensen, and K. Yvind, Nano Lett., 15, 4393 (2015). 